\title{
Analyzing student inquiry in online and offline classes during the Covid-19 pandemic through momentum and impulse worksheets
}

\author{
Habibah Khusna Baihaqi a *, Jumadi Jumadi ${ }^{\text {b }}$, Annisaa' Mardiani c, Racy Religia ${ }^{\text {d }}$ \\ Universitas Negeri Yogyakarta. Jalan Colombo No 1, Yogyakarta, 55281, Indonesia \\ a habibah0001pasca.2020@student.uny.ac.id; bjumadi@uny.ac.id; c annisaamardiani.2020@student.uny.ac.id; \\ d racyreligia.2020@student.uny.ac.id \\ * Corresponding Author.
}

\begin{abstract}
During the Covid-19 pandemic, it is necessary to develop an effective physics learning media used in a short learning time. This study aims to develop a package of worksheets based on an inquiry learning model that is integrated with traditional games. This research is a research and development using 4D model which is carried out at the define, design and develop stages. Validation was carried out by 3 experts and the worksheets were tested on 45 students of class $X$ consisting of online and offline classes. The results of the development show that the momentum practicum worksheet is 3.68 in the valid range, the law of conservation momentum practicum worksheet is 3.66 in the valid and very good range, the coefficient of restitution and type of collision practicum worksheets are 3.74 and 3.73 in the valid and very good range, also the worksheet package scored 3.67 which means valid and very good. The implementation of learning is $98.21 \%$ and the readability questionnaire shows that $82.27 \%$ of students agree that the worksheet developed is very interesting and easy to use. The achievement of the inquiry process in the online class is 86.10 while in the offline class is 93.84 . The results show that this worksheet is effective in optimizing the inquiry process both online and offline so that it can be used to investigate the topic of momentum and impulse by class $X$ science students during the Covid-19 pandemic.

Keywords: Covid-19 pandemic; inquiry; worksheet
\end{abstract}

How to Cite: Baihaqi, H. K., Jumadi, J., Mardiani, A., \& Religia, R. (2021). Analyzing student inquiry in online and offline classes during the covid-19 pandemic through momentum and impulse worksheets. Momentum: Physics Education Journal, 5(2), 161-174. https://doi.org/10.21067/mpej.v5i2.5567

\section{Introduction}

Starting from March 11, 2020, the first time Covid-19 was declared as a world pandemic by WHO (Atmojo et al., 2020) and has been a pandemic for more than one year. During that time, the implementation of social and physical distancing causes the learning process to be online (Atmojo et al., 2020 ; Juanda et al., 2021). The challenges of continuing to learn amid the Covid-19 pandemic are faced by educators, such as training student for independent learning, generating learning innovations, and providing access to material other than textbooks (Juanda et al., 2021).

Motivation given by educators to students in online learning has a positive relationship that accompanies inquiry (Adler et al., 2018; Scogin \& Stuessy, 2015). This positive relationship (Adler et al., 2018) help in training the students' learning independence. There is a relationship between inquiry-based work and student curiosity (Uiterwijk-Luijk et al., 2019). They mentioned that inquiry requires a habit of discovering and being literate. Through data literacy, it can be transformed into knowledge, which is transformed into action (Marsh \& Farrell, 2015) that stimulates good practice 
and affects student learning (Katz \& Dack, 2014). Therefore, inquiry-based work can be applied as a learning innovation in the Covid-19 pandemic.

Inquiry-based work can be made into the form of worksheets. The development of student worksheet is in accordance with the era of digital technology in the 21st century which presents animation and video packages (Mardiyanto, 2019; Oktasari et al., 2019) that support online learning. Learning models help teachers organize the material to teach (Leasa et al., 2016; Setiawan et al., 2020). Student worksheets can be adapted to inquiry as an effective medium for student physics conceptual achievement that encourages students to be actively involved in learning (Rani et al., 2017); directing the learning and the process of developing student learning (Arsal, 2017) and being able to guide or direct students to develop their abilities (Kunt \& Tortop, 2017) to think about how to analyze the process of physics phenomenon (Sutarto et al., 2018).

Inquiry-based learning provides new challenges related to student motivation because inquiry changes the traditional learning environment towards the necessity for students to reconstruct meaning, where motivation is the core of learning, engagement, better results, and completion of students' knowledge construction (Adler et al., 2018). The reconstruction of student knowledge plays an important role in a strong understanding process.

Strong and meaningful understanding such as in the topic of momentum and impulse (Saifullah et al., 2017) is needed, considering that this topic is used in solving mechanical problems involving forces that work for a certain time (Serway \& Jewett, 2018). In line with (Purwaningsih et al., 2020) who stated that Momentum and Impulse material is very important in learning physics and is close to student life, also the meaning and effects of learning instructions in the topic of impulses and momentum are still unclear. Thus, inquiry-based worksheets are needed as an effective medium that is more than textbooks to make students active, to reconstruct meaning on the topic of momentum and impulse, and as a learning innovation in the middle of the Covid-19 pandemic.

In connection with the rapid development of information technology, it is directly or indirectly one of the causes for the displacement of cultural values. Cultural values are contained in various traditional games owned by the Indonesian people. Various traditional games passed down through generations to support children's emotional and social skills developments of object control (Trajkovik et al., 2018), and positively affects the overall development of the children (Kovačević \& Opić, 2014). It is very important for students to enjoy learning while exploring new media and technologies, games, and modeling (Leasa et al., 2021).

Traditional games as an expression of native culture that contribute to the common identity of humanity are threatened with disappearance or extinction due to the influence of globalization and the harmonization of the diversity of world heritage. So, it is necessary to integrate traditional games in a physics learning media to preserve the cultural values of the nation and will shift pedagogical approach from teacher-centered to student-centered (Trajkovik et al., 2018). In the 21st century, a valuable asset to the school environment is a will of learning, which includes facilitating student curiosity through inquiry, organizing fun workshops, simulating real-world contexts to gain a richer understanding of learning material (Chu et al., 2017). Those assets can be possibly built through the integration of traditional games on student worksheets.

Initial studies at SMAN 1 Singosari showed that, during the Covid-19 Pandemic, the duration of 1 hour of lessons was only 25 minutes, students did not have the opportunity to do simple practicums, classes were divided into offline and online, and students had difficulty focusing on learning, especially in online learning. Providing lots of practice to students through the inquiry process can influence higher order thinking skills (Wartono et al., 2018), explore new media for students to have a fun learning (Leasa et al., 2016), and making students focus on learning by inquiry model (Wartono et al., 2019). Thus, this study aims to develop an inquiry-based student worksheet package assisted by traditional games on the momentum and impulse topic and to analyze the differences in inquiry achievement for students in online and offline classes. 


\section{Method}

This research is a development research by adapting the 4D development model, namely define, design, develop, and disseminate from Thiagarajan (Rani et al., 2017). However, this research is only carried out until the develop stage, with the research procedure shown in Figure 1.

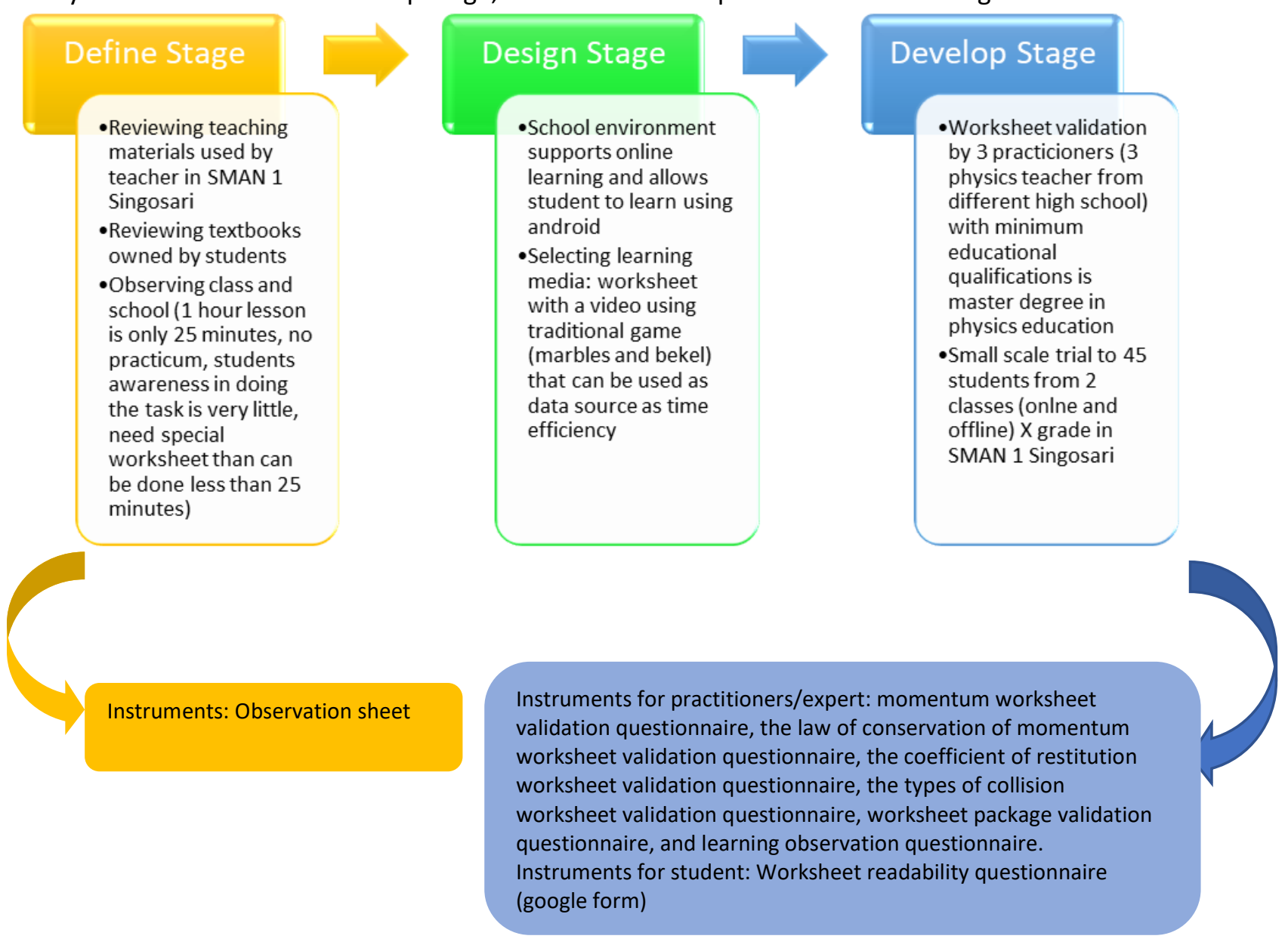

Figure 1. Research procedures and instruments

The validation results are averaged and categorized based on the feasibility of the four worksheets that have been developed. Student responses to the worksheets are accumulated and categorized on how interesting the worksheets are for students to use.

Small-scale trials were carried out by giving momentum worksheets to 2 classes with a total of 45 students. Class selection is based on classes that have reached the same material. One class only has 16 students because it is the last class with the least number of students. The 16 students received an offline schedule during the research. The other class with online schedule consists of 29 students. Then, scoring guidelines for each stage of inquiry in the worksheet was made to find the percentage value of each student's achievement for each inquiry process for both offline and online classes. Learning observation questionnaire was filled out by the physics teacher as an observer during the research to see how far the learning can be carried out.

\section{Results and Discussion}

\section{Product Eligibility}

The student worksheet package is divided into 4 practicums. The momentum and impulse topic is divided into two different practicums namely momentum and impulse. Then, the law of conservation of momentum practicum, and types of collisions practicum which can be determined by 
Momentum: Physics Education Journal, 5 (2), 2021, 164

Habibah Khusna Baihaqi, Jumadi Jumadi, Annisaa' Mardiani, Racy Religia

the value of the coefficient of restitution. The results of the momentum practicum student worksheets validation can be seen in Table 1.

Table 1. Validation Result of Momentum Worksheet

\begin{tabular}{|c|c|c|c|c|c|}
\hline \multirow{2}{*}{ Indicator } & \multicolumn{3}{|c|}{ Validator } & \multirow{2}{*}{ Average } & \multirow{2}{*}{ Criteria } \\
\hline & V1 & V2 & V3 & & \\
\hline Cover & 4 & 4 & 4 & 4 & Very good \\
\hline Identity & 4 & 4 & 4 & 4 & Very good \\
\hline Learning goals & 4 & 3,4 & 4 & 3,8 & Very good \\
\hline Problem approach & 4 & 3,4 & 3,4 & 3,6 & Very good \\
\hline Making hypotheses & 3,75 & 2,75 & 4 & 3,5 & Very good \\
\hline $\begin{array}{l}\text { Momentum practicum data retrieval video (using traditional } \\
\text { game, marble) }\end{array}$ & 4 & 3,33 & 4 & 3,78 & Very good \\
\hline Collecting Information and Executing the Inquiry & 3,83 & 3,17 & 4 & 3,67 & Very good \\
\hline Comparing results to the physics view & 3,75 & 3,25 & 3,75 & 3,58 & Very good \\
\hline Summarizing and interpreting & 3,25 & 3,5 & 3,75 & 3,50 & Very good \\
\hline
\end{tabular}

Source: Modification from (Tsivitanidou, 2018 ; Suchman, 1961)

The average validation result for Worksheet 1 is 3.68 and it was included in category A or very good. The composition of student worksheet follows inquiry learning. The first is the episode analysis, which is the form of object and system identification. The second one is determination of relevance, namely collecting data through experiments on filmed demonstrations. The last is induction of relational construct, namely finding principles and relationships that regulate changes that occur (Suchman, 1961).

The episode analysis was interpreted into problem approach and making hypotheses, determination of relevance manifested in Momentum practicum data retrieval video and Collecting Information and Executing The Inquiry, and induction of relational construct embodied in Comparing results to the physics view, then summarizing and interpreting. The second worksheet development is for the law of conservation of momentum practicum. The validation result for second worksheet is presented in Table 2.

Table 2. Validation Result of The Law of Conservation of Momentum Worksheet

\begin{tabular}{lccccc}
\hline \multicolumn{1}{c}{ Indicator } & \multicolumn{3}{c}{ Validator } & \multirow{2}{*}{ Average } & \multirow{2}{*}{ Criteria } \\
\cline { 2 - 5 } & V1 & V2 & V3 & \\
\hline Cover & 4 & 4 & 4 & 4 & Very good \\
Identity & 4 & 4 & 4 & 4 & Very good \\
Learning goals & 4 & 3 & 4 & 3,67 & Very good \\
Problem approach & 3,8 & 3,4 & 3,4 & 3,53 & Very good \\
Making hypotheses & 4 & 3 & 4 & 3,67 & Very good \\
Law of conservation of momentum practicum data retrieval video & 4 & 2,83 & 4 & 3,61 & Very good \\
(using traditional game, marble) & & & & & \\
Collecting Information and Executing the Inquiry & 4 & 3 & 4 & 3,67 & Very good \\
Comparing results to the physics view & 4 & 3 & 3,8 & 3,60 & Very good \\
Summarizing and interpreting & 3,75 & 3,50 & 3,75 & 3,67 & Very good \\
\hline
\end{tabular}

Source: Modification from (Suchman, 1961 ; Tsivitanidou, 2018)

The average validation result for the Law of Conservation of Momentum Worksheet was 3.66 and it was included in category A or very good. (Tsivitanidou, 2018) divided the inquiry step into an initiation phase, which consists of a problem-based approach and considering students preconception. Then the practicing phase which consists of planning, making hypotheses, collecting information, and executing information. Next is the final phase, namely reviewing, which consists of comparing the results to the scientific view, creating models and argumentation, and reinforcing the scientific view. The three phases from (Tsivitanidou, 2018) and three phases from (Suchman, 1961) are conceptualized into an arrangement of inquiry activities on the four student worksheets. The recapitulations of validation of the third and fourth student worksheets are presented in Table 3 and 
Momentum: Physics Education Journal, 5 (2), 2021, 165

Habibah Khusna Baihaqi, Jumadi Jumadi, Annisaa' Mardiani, Racy Religia

Table 4 below. Third practicum is the coefficient of restitution of bekel and the fourth practicum is the types of collision.

Table 3. Validation Result of Coefficient of Restitution Worksheet

\begin{tabular}{lccccc}
\hline & \multicolumn{3}{c}{ Indicator } & \multicolumn{3}{c}{ Validator } & Average & Criteria \\
\cline { 2 - 5 } & V1 & V2 & V3 & & Very good \\
Cover & 4 & 4 & 4 & 4 & Very good \\
Identity & 4 & 4 & 4 & 4 & Very good \\
Learning goals & 4 & 3,25 & 4 & 3,75 & Very good \\
Problem approach & 4 & 3,40 & 3,40 & 3,60 & Very \\
Making hypotheses & 4 & 3 & 4 & 3,67 & Very good \\
Coefficient restitution practicum data retrieval video (using & 4 & 3,67 & 4 & 3,89 & Very good \\
traditional game, bekelan) & & & & & \\
Collecting Information and Executing the Inquiry & 4 & 3,29 & 4 & 3,76 & Very good \\
Comparing results to the physics view & 4 & 3,20 & 3,80 & 3,67 & Very good \\
Summarizing and interpreting & 3,75 & 3,25 & 3,75 & 3,58 & Very good \\
\hline
\end{tabular}

Source: Modification from (Suchman, 1961 ; Tsivitanidou, 2018)

The average validation result for coefficient of restitution worksheet is 3,74 and included to valid and very good category.

Table 4. Validation Result of Types of Collisions Worksheet

\begin{tabular}{lcccccc}
\hline \multicolumn{1}{c}{ Indicator } & \multicolumn{3}{c}{ Validator } & \multirow{2}{*}{ Average } & Criteria \\
\cline { 2 - 5 } & V1 & V2 & V3 & & Very good \\
Cover & 4 & 4 & 4 & 4 & Very good \\
Identity & 4 & 4 & 4 & 4 & Very good \\
Learning goals & 4 & 3,25 & 4 & 3,75 & Very good \\
Considering pupils' preconception & 4 & 3 & 3,67 & 3,56 & Very good \\
Making hypotheses & 4 & 3,50 & 3,50 & 3,67 & 3,83 & Very good \\
Collisions' practicum data retrieval video & 4 & 3,59 & 4 & 3,71 & Very good \\
Collecting Information and Executing The Inquiry & 4 & 3,14 & 4 & 3,58 & Very good \\
Summarizing and interpreting & 3,50 & 3,25 & 4 & 3,58
\end{tabular}

Source: Modification from (Suchman, 1961; Tsivitanidou, 2018)

Table 5. Validation Result of Student Worksheet Package

\begin{tabular}{lccccc}
\hline \multicolumn{1}{c}{ Indicator } & \multicolumn{3}{c}{ Validator } & Average & Criteria \\
\cline { 2 - 5 } & V1 & V2 & V3 & & Very good \\
Inquiry-based worksheets & 4 & 4 & 4 & 4 & Very good \\
Application of traditional games in worksheet & 4 & 3 & 4 & 3,67 & Very good \\
Development of data retrieval videos & 4 & 3,25 & 4 & 3,75 & Very good \\
Reading literacy in the worksheets & 4 & 3 & 4 & 3,67 & Very good \\
Learning media during the Covid-19 pandemic & 4 & 3,25 & 4 & 3,75 & Very good \\
Breadth of content & 4 & 2 & 4 & 3,33 & Very good \\
Accuracy of content & 4 & 3,25 & 4 & 3,75 & Very good \\
Depth of content & 4 & 3 & 4 & 3,67 & Very good \\
Cover & 3 & 2,5 & 4 & 3,17 & Very good \\
Layout & 3,5 & 3,5 & 4 & 3,67 & Very good \\
Color & 4 & 3 & 3,5 & 3,50 & Very good \\
Pictures & 4 & 3 & 4 & 3,67 & Very good \\
Font & 4 & 2,5 & 3 & 3,17 & Very good \\
Consistency & 4 & 4 & 4 & 4 & Very good \\
Balance & 4 & 3 & 4 & 3,67 & Very good \\
Student centered & 4 & 4 & 4 & 4 & Very good \\
Language & 3,67 & 3 & 4 & 3,56
\end{tabular}

Source: Modification from (Rahmawati et al., 2018; Rani et al., 2017) 
The average validation result for type of collision worksheet is 3.73 and it was included in valid or very good category. An analysis was also carried out on the student Worksheet package to see how well these four worksheets were as a learning resource to explore students' inquiry skills (Fernandes et al., 2019), and video as a source of data to support student and teacher activities in science learning (Clark et al., 2016). Analysis result for student worksheet package was showed in Table 5.

The average validation result for the student worksheet package was 3.67 and it was included in valid category or very good. Besides quantitative data, qualitative data were also obtained, namely suggestions from the validator. Some suggestions from the validator and the revisions showed in Table 6.

Table 6. Product Revision Based on Suggestions from Validator

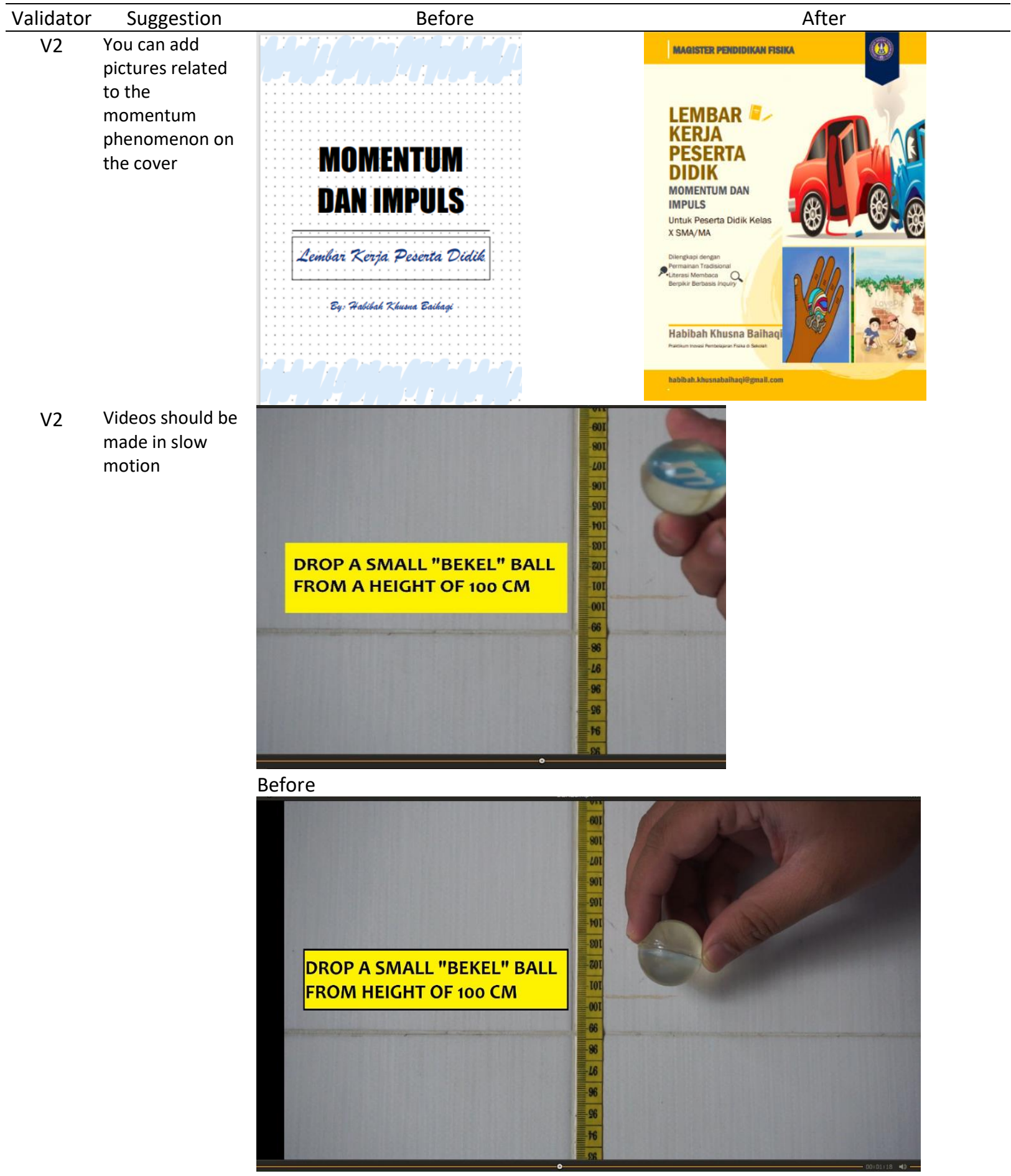


Momentum: Physics Education Journal, 5 (2), 2021, 167

Habibah Khusna Baihaqi, Jumadi Jumadi, Annisaa' Mardiani, Racy Religia

\begin{tabular}{|c|c|c|c|}
\hline Validator & Suggestion & Before & After \\
\hline \multirow[b]{2}{*}{ V1 } & \multirow[b]{2}{*}{$\begin{array}{l}\text { Is watching } \\
\text { videos a learning } \\
\text { goal? }\end{array}$} & \multicolumn{2}{|l|}{ After: The video has been made in slow motion. } \\
\hline & & $\begin{array}{l}\text { Learning goals on momentum practicum: } \\
\text { Students can analyze the quantities of physics } \\
\text { in marble games through a problem approach } \\
\text { and watch videos as a source of collecting data. }\end{array}$ & $\begin{array}{l}\text { The first learning goals on momentum } \\
\text { practicum change to be: } \\
\text { Students can analyze the quantities of } \\
\text { physics in marble games through a problem } \\
\text { approach with a video data source }\end{array}$ \\
\hline \multirow[t]{3}{*}{ V1 } & \multirow{3}{*}{$\begin{array}{l}\text { Why use the } \\
\text { information of } \\
\text { bekel and } \\
\text { marbles in the } \\
\text { problem } \\
\text { approach if the } \\
\text { data collection } \\
\text { and investigation } \\
\text { use different size } \\
\text { of bekel ball? }\end{array}$} & $\begin{array}{l}\text { To make it easier, try to observe the following } \\
\text { illustration! } \\
\text { If a "bekel" ball (blue) and a marble (green) are } \\
\text { both dropped from a height of } 20 \mathrm{~cm} \text {, what do } \\
\text { you think will happen? }\end{array}$ & $\begin{array}{l}\text { To make it easier, try to observe the } \\
\text { following illustration! } \\
\text { If } 2 \text { "bekel" balls are dropped together from } \\
\text { a height of } 20 \mathrm{~cm} \text { (the blue bekel is bigger), } \\
\text { what do you think will happen? }\end{array}$ \\
\hline & & 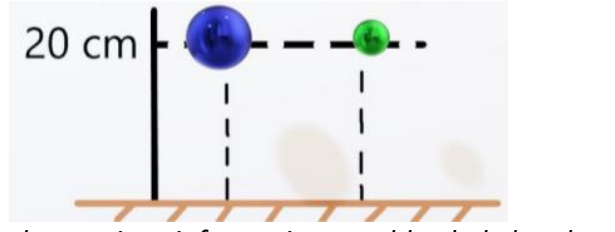 & $20 \mathrm{~cm} \mid \begin{array}{rr}0--1 \\
1 & 1 \\
1 & 1 \\
1 & 1 \\
1 & 1\end{array}$ \\
\hline & & $\begin{array}{l}\text { the previous injormation was biue bekel ana } \\
\text { green marbles }\end{array}$ & $\begin{array}{l}\text { Information on the problem approach } \\
\text { changes to be different sizes of green and } \\
\text { blue bekel balls (adjusting video and } \\
\text { observation tables in the collecting } \\
\text { information and executing the inquiry step) }\end{array}$ \\
\hline
\end{tabular}

Readability/Ease of Using Product

Readability questionnaires are distributed via google form to students. A total of 45 students filled out a form consisting of 25 statements. The 25 statements were born from 5 categories. Each statement is a positive statement. In Table 7, the average percentage value of student responses for each category of statements is presented.

Table 7. Analyzing Students' Responses

\begin{tabular}{|c|c|c|c|}
\hline Category & $\begin{array}{l}\text { Amount of } \\
\text { statement }\end{array}$ & $\begin{array}{l}\text { Average } \\
\text { Percentage } \\
\text { Value }(\%)\end{array}$ & Criteria \\
\hline $\begin{array}{l}\text { Students like and are interested in every part of the worksheet (problem } \\
\text { approach, making hypotheses, drawing graphs, arrangements, etc.) }\end{array}$ & 5 & 82,67 & $\begin{array}{c}\text { Very } \\
\text { suitable }\end{array}$ \\
\hline Students can have fun while working on worksheets & 6 & 82,87 & $\begin{array}{l}\text { Very } \\
\text { suitable }\end{array}$ \\
\hline $\begin{array}{l}\text { Students feel helped in learning to understand the material and make } \\
\text { connections with everyday life (traditional games on the concepts of } \\
\text { momentum and impulse) }\end{array}$ & 5 & 83,56 & $\begin{array}{c}\text { Very } \\
\text { suitable }\end{array}$ \\
\hline $\begin{array}{l}\text { Students do not find it difficult to complete and easily understand the } \\
\text { instructions in the worksheet (every single sentence, video, traditional } \\
\text { games) }\end{array}$ & 3 & 80,74 & $\begin{array}{c}\text { Very } \\
\text { suitable }\end{array}$ \\
\hline $\begin{array}{l}\text { Students can receive this worksheet in offline or online learning, during a } \\
\text { pandemic, or after a pandemic, and this worksheet looks different from } \\
\text { what they have encountered before }\end{array}$ & 6 & 81,02 & $\begin{array}{l}\text { Very } \\
\text { suitable }\end{array}$ \\
\hline
\end{tabular}

Overall, the average score was $82.27 \%$, so these worksheets were very attractive and easy to use. The limited test was carried out in two classes to work on the momentum practicum worksheet and obtained $98.21 \%$ learning implementation, which means that the worksheet is very practical. Therefore, it is worth using. $80.74 \%$ of students stated that they were able to complete the inquiry stage in this worksheet and $82.87 \%$ of students said they had fun while doing it. This worksheet also succeeded in fulfilling a will for learning and facilitating someone's curiosity through inquiry rather than making students frustrated and bored (Chu et al., 2017). In addition, $81.02 \%$ of students agreed to possibly use this worksheet during the Covid-19 pandemic, an average of 3.75 was obtained from the validator on the aspect of learning media during the pandemic. 
Video development using traditional game properties as a data source also supports online learning (Roth et al., 2011).Videos can be used to facilitate questions, create meaning and change ideas (Mayo et al., 2009). Games are an inquiry feature for predicting-observing-explaining strategies, problem solving, and variable manipulation (Fernandes et al., 2019). Games can also increase the depth of understanding mediated by technology (Strømme \& Furberg, 2015), since children prefer technology-based games. It is necessary to make efforts to re-exist the cultural heritage of traditional games, so that children can easily find them. In addition, the validator also said that the video about the marbles and bekel ball which was developed with a description of physical quantities greatly assisted the effective learning process during the pandemic. However, they also suggested that when the pandemic ended, data collection should be carried out directly by students with videos that were used as examples as a means to provide hands-on experience in playing traditional games.

\section{Implementation of Momentum Worksheet}

Small-scale trials were carried out on one worksheet, namely the momentum worksheet. Momentum worksheets were distributed to 45 students of class $X$ at SMAN 1 Singosari. During the Covid-19 pandemic, learning activities are limited with the distribution of online-offline learning schedules depending on the student absent number, and the duration of learning both online and offline is 25 minutes. There are 2 classes included in this research, namely online and offline classes. In classes that happen to receive offline learning, the momentum worksheet can be completed by students in 15 minutes so that the remaining 10 minutes are used to explain impulse material and provide examples of questions. Based on the effectiveness of the time in completing this worksheet, and from the observer's questionnaire filled out by the teacher as an observer when the researcher conducted learning, it was found that this worksheet was effectively applied during a pandemic. While in the offline class, a meeting was held via google meet and students were given instructions to work on the worksheet. The worksheets have been shared beforehand when they get the schedule to enter classroom. The results of student work were collected on the next day.

Students are able to learn fully focused by using the inquiry model (Wartono et al., 2018). Based on the results of student work, Figure 2 shows the comparison of the percentage of achievement of the inquiry process in the momentum worksheet between students who study online and offline.

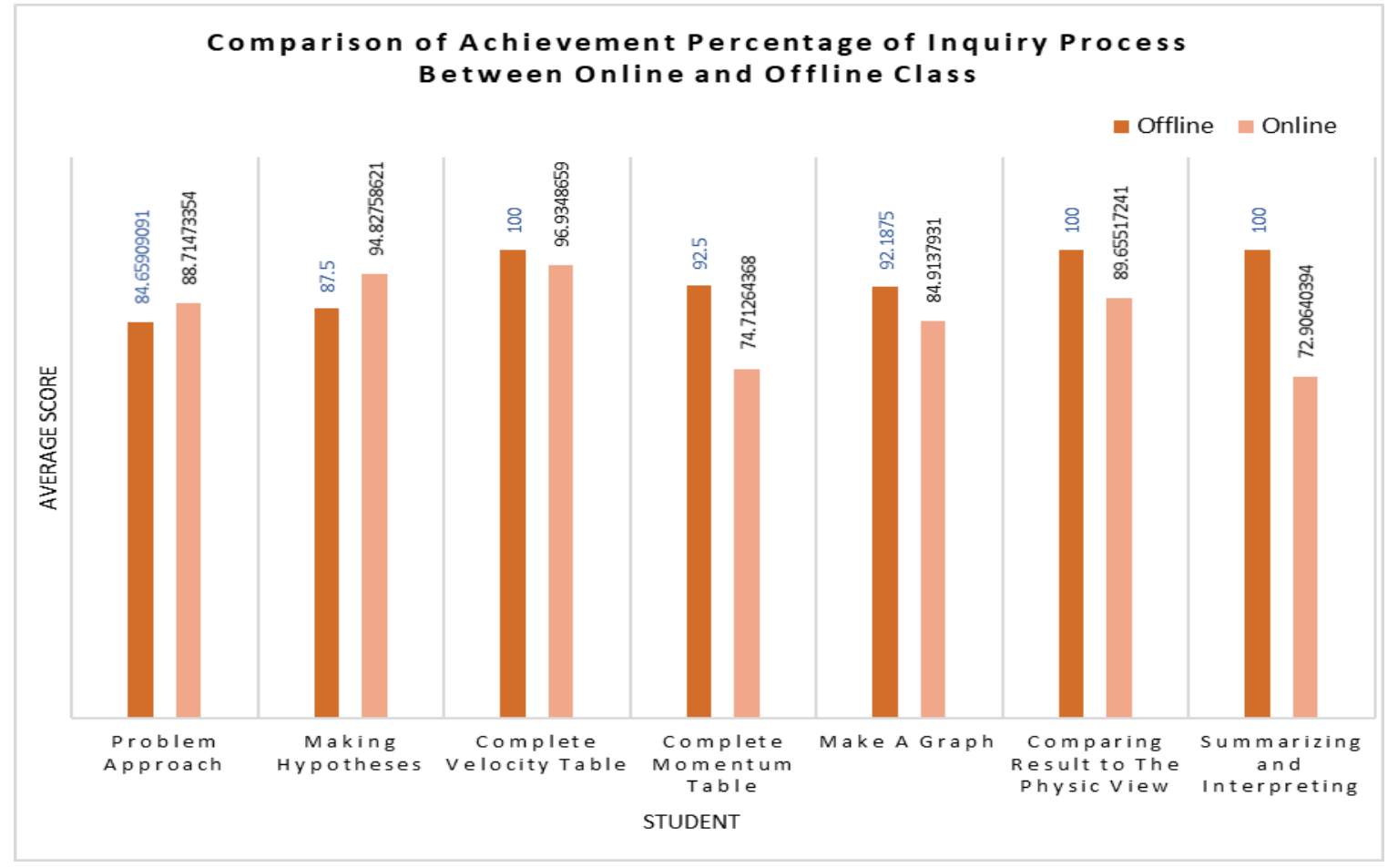

Figure 2. Comparison of Achievement Percentage of Inquiry Process Between Online and Offline Class 
Based on the Figure 2, at the stage of problem approach and making hypotheses, students who study online get a higher average score. In this section, students are asked to fill in a prediction table for physics quantities in the marbles game. Due to working at home, the online class has an opportunity to open a textbook or browse the Internet to complete the prediction of the physics quantity and its units. In contrast to students in offline class who are supervised directly during the work, so there is no opportunity to open the textbook, some of them have not correctly answered the units on the physical quantities of velocity and acceleration, such as units being swapped and answered with the same units. In this case, the memory of students in offline class dealing with previous material can be clearly seen. However, with the achievement of $84.7 \%$, students in the offline class have good initial knowledge.

Completing velocity table, momentum table, and drawing a graph are part of the stage of collecting information and executing the inquiry in the inquiry learning model. At this stage, offline class students are superior to online class. This possibly because they watched the video of practicum 1 (marbles move at different speeds) simultaneously assisted by the teacher using the LCD, so they could focus on paying attention to the values in the video and filling out the speed table. Meanwhile, they can also freely ask the teacher when they do not understand how to fill in the momentum table. While in online class, they are given a video link so they can observe it individually at home. The striking difference is that when filling out the momentum table, online class and offline class have a $17.8 \%$ achievement gap. In providing corrections, in online class students were less careful in submitting the speed values that had been obtained previously in the momentum table. Some have filled it correctly, but when calculating the momentum value, the velocity value that is submitted is the amount of time. There are also those who are not correct when converting the mass of marbles from grams to kilograms so that the momentum value obtained is not correct. There are also those who convert with $10^{-3}$ multiplication, but are not included in the momentum table. Figure 3 and Figure 4 are the example of student work in completing momentum table.

\begin{tabular}{|c|l|l|l|l||}
\hline \multicolumn{5}{|c|}{ 4. Calculate the momentum value of each marble by filling in the blank in this following table! } \\
\hline Number & Mass (gram) & Mass $(\mathrm{kg})$ & Velocity $(\mathrm{m} / \mathrm{s})$ & Momentum $(\mathrm{kg} \mathrm{m} / \mathrm{s})$ \\
\hline 1. & $\mathrm{~m}_{1}=5,6 \mathrm{gram}$ & $\mathrm{m}_{1}=5,6 \times 10^{-3} \mathrm{~kg}$ & $\overline{v_{1}}=0,29 \mathrm{~m} / \mathrm{s}$ & $\begin{array}{l}\mathrm{p}_{1}=\mathrm{m}_{1} \times \overline{v_{1}} \\
\mathrm{p}_{1}=0,056 \times 0,29 \\
\mathrm{p}_{1}=11,648 \mathrm{~kg} \mathrm{~m} / \mathrm{s}\end{array}$ \\
\hline 2. & $\mathrm{~m}_{2}=5,6 \mathrm{gram}$ & $\mathrm{m}_{2}=5,6 \times 10^{-3} \mathrm{~kg}$ & $\overline{v_{2}}=0,58 \mathrm{~m} / \mathrm{s}$ & $\begin{array}{l}\mathrm{p}_{2}=\mathrm{m}_{2} \times \overline{v_{2}} \\
\mathrm{p}_{2}=0,056 \times 0,58 \\
\mathrm{p}_{2}=3,248 \mathrm{~kg} \mathrm{~m} / \mathrm{s}\end{array}$ \\
\hline 3. & $\mathrm{~m}_{3}=5,6$ gram & $\mathrm{m}_{3}=5,6 \times 10^{-3} \mathrm{~kg}$ & $\overline{v_{3}}=2,08 \mathrm{~m} / \mathrm{s}$ & $\begin{array}{l}\mathrm{p}_{3}=\mathrm{m}_{3} \times \overline{v_{3}} \\
\mathrm{p}_{3}=0,056 \times 2,08 \\
\mathrm{p}_{3}=1,624 \mathrm{~kg} \mathrm{~m} / \mathrm{s}\end{array}$ \\
\hline $\begin{array}{l}\text { The value is deducted 2 points due to the inaccurate calculation (mass value in third column is not properly substituted } \\
\text { into the mass in the momentum column) }\end{array}$ \\
\hline
\end{tabular}

Figure 3. Example of Student Answer on Online Class

\begin{tabular}{|c|c|c|c|c|}
\hline Number & Mass (gram) & Mass (kg) & Velocity $(\mathrm{m} / \mathrm{s})$ & Momentum (kg m/s) \\
\hline 1. & $m_{1}=5,6$ gram & $\mathrm{m}_{1}=0,0056 \mathrm{~kg}$ & $\overline{v_{1}}=0,287 \mathrm{~m} / \mathrm{s}$ & $\begin{array}{l}\mathrm{p}_{1}=\mathrm{m}_{1} \times \overline{v_{1}} \\
\mathrm{p}_{1}=0,0056 \times 0,287 \\
\mathrm{p}_{1}=0,0016 \mathrm{~kg} \mathrm{~m} / \mathrm{s}\end{array}$ \\
\hline 2. & $m_{2}=5,6$ gram & $\mathrm{m}_{2}=0,0056 \mathrm{~kg}$ & $\overline{v_{2}}=0,578 \mathrm{~m} / \mathrm{s}$ & $\begin{array}{l}\mathrm{p}_{2}=\mathrm{m}_{2} \times \overline{v_{2}} \\
\mathrm{p}_{2}=0,0056 \times 0,578 \\
\mathrm{p}_{2}=0,0032 \mathrm{~kg} \mathrm{~m} / \mathrm{s}\end{array}$ \\
\hline 3. & $m_{3}=5,6$ gram & $\mathrm{m}_{3}=0,0056 \mathrm{~kg}$ & $\overline{v_{3}}=2,083 \mathrm{~m} / \mathrm{s}$ & $\begin{array}{l}p_{3}=m_{3} \times \overline{v_{3}} \\
p_{3}=0,0056 \times 2,083 \\
p_{3}=0,0116 \mathrm{~kg} \mathrm{~m} / \mathrm{s}\end{array}$ \\
\hline
\end{tabular}

Figure 4. Example of Student Answer on Offline Class 
Offline and online classes are both good at drawing graphs. They are able to place the lowest to the highest values on both the $x$-axis (velocity) and the $y$-axis (momentum). However, in the previous momentum table in the offline class, some students were doing wrong in entering data, the momentum value on the graph did not show the correct value.

In comparing the results to the physics view, although the offline class is superior to the online class, it doesn't show that much of a gap when compared to the results of their work on summarizing and interpreting. Student answers on summarizing and interpreting in online class is presented in Figure 5 and student answer on summarizing and interpreting section in offline class is presented in Figure 6.

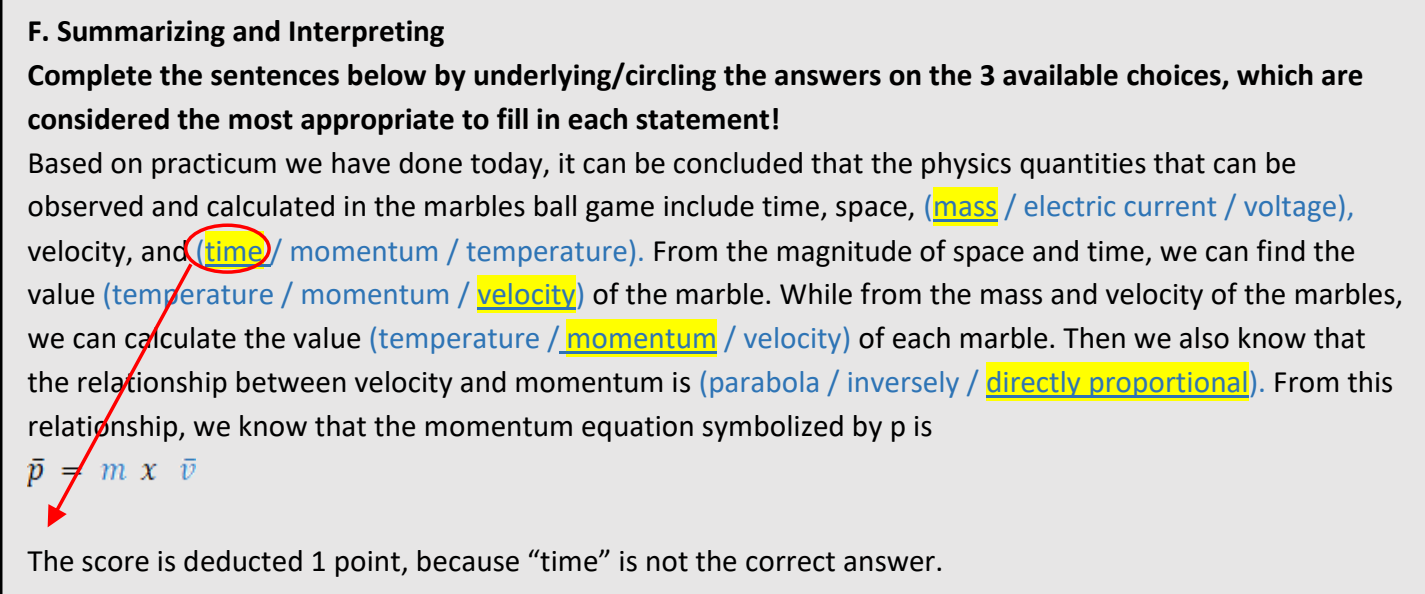

Figure 5. Example of Student Answer in Summarizing and Interpreting in Online Class

\begin{abstract}
F. Summarizing and Interpreting
Complete the sentences below by underlying/circling the answers on the $\mathbf{3}$ available choices, which are considered the most appropriate to fill in each statement!

Based on practicum we have done today, it can be concluded that the physics quantities that can be observed and calculated in the marbles ball game include time, space, (mass / electric current / voltage), velocity, and (time_/momentum / temperature). From the magnitude of space and time, we can find the value (temperature / momentum / velocity) of the marble. While from the mass and velocity of the marbles, we can calculate the value (temperature / momentum / velocity) of each marble. Then we also know that the relationship between velocity and momentum is (parabola / inversely / directly proportional). From this relationship, we know that the momentum equation symbolized by $\mathrm{p}$ is

$\bar{p}=m x \bar{v}$

The score is not deducted because all the answers are correct.
\end{abstract}

Figure 6. Example of Student Answer in Summarizing and Interpreting in Offline Class

In summarizing and interpreting, online class students are less careful in reading the sentence structure "physical quantities that can be observed and calculated in the game of marbles include time, distance traveled, mass, speed, and ...". Most students choose "time", not "momentum". In fact, the magnitude of "time" has been mentioned at the beginning of the sentence so it doesn't need to be repeated. Offline class students are able to answer correctly because they work together under the guidance of the teacher. One student reads the sentence and another student answers by circling the answer. In this way, students become more focused and able to answer correctly. With instructions explaining why there is a gap, students' perceptions become deeper and gain higher knowledge (Sinha \& Kapur, 2021). Students need to be considered as partners in open conversation, and the teacher's job is to guide and support students in their every response (Schrijvers et al., 2019).

Overall, the distribution of individual student scores in offline class showed in Figure 7 while distribution of individual student scores in online class showed in Figure 8. 


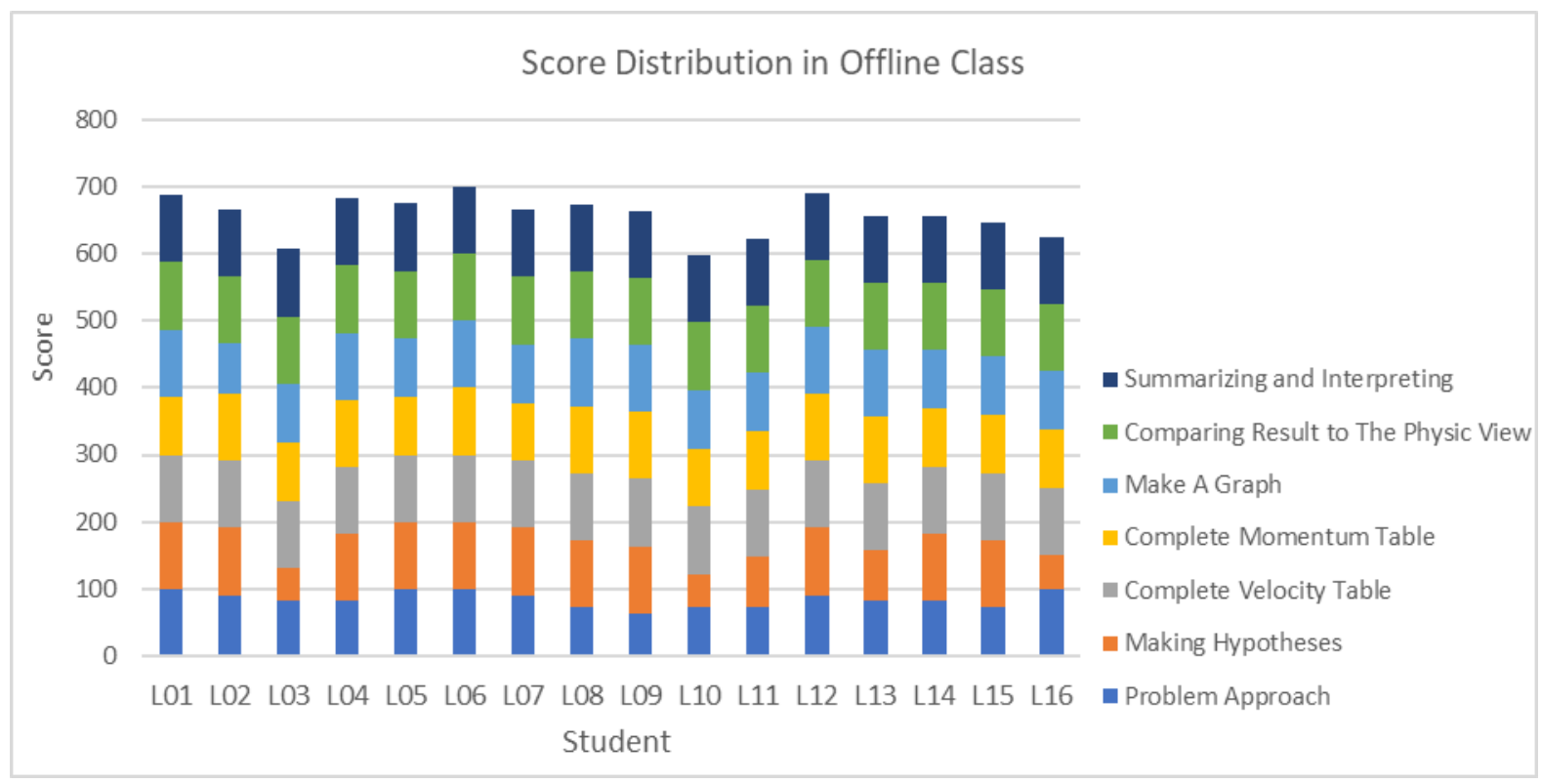

Figure 7. Individual Score Distribution in Offline Class

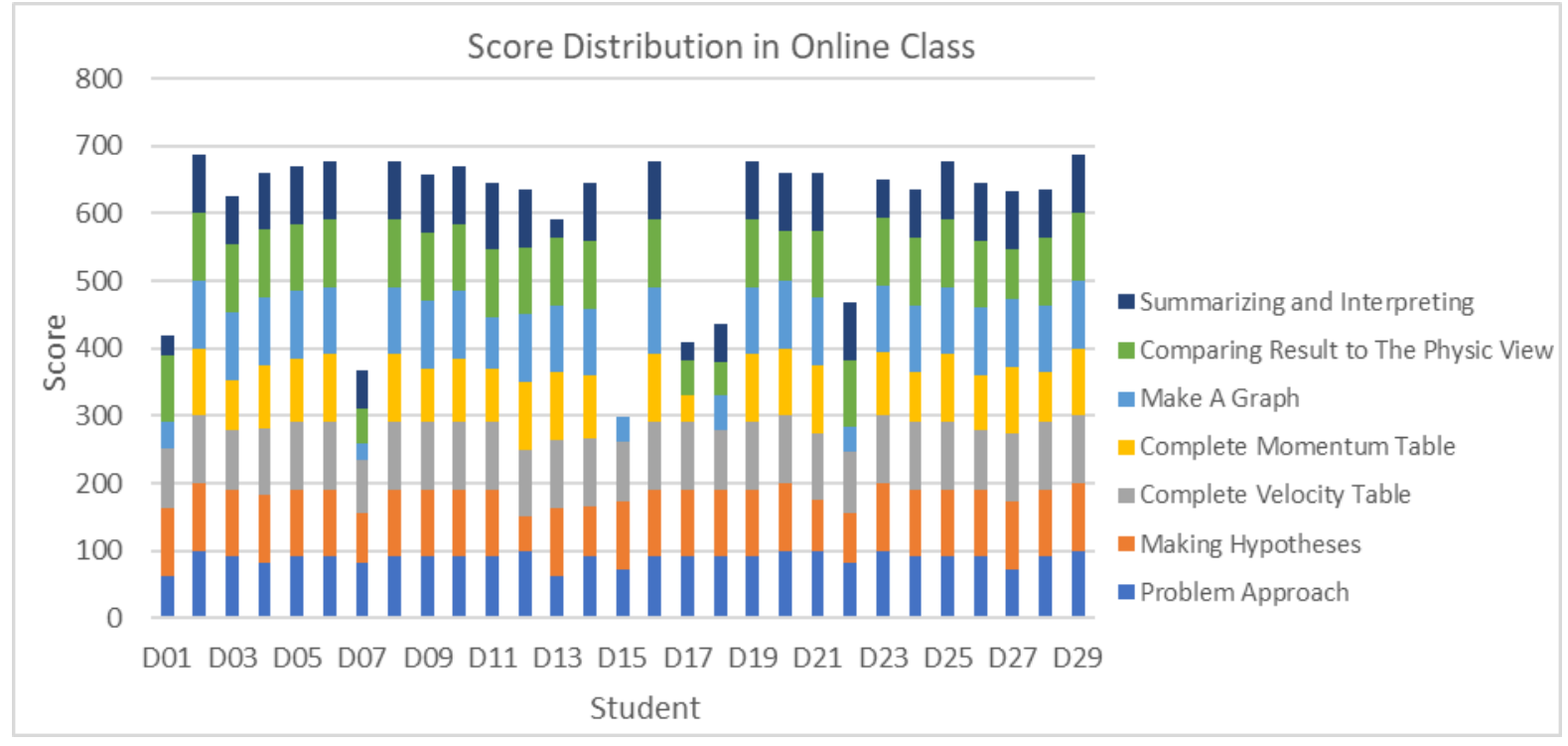

Figure 8. Individual Score Distribution in Online Class

Overall, based on the Inquiry process, the average offline class is 93.84 and the online class is 86.10. The distance between the two values is 7.74. Meanwhile, based on the scores obtained, the average score of the offline class is 93.94 and the online class is 86.00 . The distance between the two values is 7.94. It means, both in terms of the percentage of the inquiry process and the overall score, online and offline classes have a success rate of $>85 \%$. Therefore, it can be said that momentum worksheets are effective in stimulating the inquiry process of students, both those who study online and offline with limited time.

Based on the description of the online and offline student inquiry process, the achievement of the inquiry process in offline class is better. This is because the teacher can directly guide the students and students can freely discuss and ask the teacher. Some of the student responses to the momentum worksheet are as follows.

D17 "The learning system in this worksheet makes its own interest"

L16 "it is very good and interesting but I still need a little teacher guidance in the process"

L06 "The content of the worksheet is easy for me to remember and learn, but it would be better if it was practiced together with students" 
D19 "The practicum video is very clear and it is easy for me to understand this material, but I want to do direct practice together when pandemic ended".

D14 "It is good to be a media for learning physics both online/offline, and it is better to maintain it in the future".

Students responded positively to this worksheet, but many of them also wanted to do practicum together playing marbles instead of watching videos. This is in line with the validator's opinion that the developed video is very good. Since it can optimize learning shortly, it is suitable for use as a data source. But when the pandemic ended, the second expert stated that videos should be used as demonstrations and then carried out by children directly to get data. Real-life situations or hands-on experiences make students have an opportunity to engage in real-life problem solving and practice without systematic guidance from the teacher which possibly cause risks (Chernikova et al., 2020).

\section{Conclusion}

The results of research and development show that the student practicum worksheets of momentum, the law of conservation of momentum, object's coefficient of restitution finding, and types of collisions are valid and feasible to use. The student worksheet package is also in the very good category in using inquiry learning model as the base of the integration of traditional games in video practicum data sources, and as a learning media during the Covid-19 pandemic. Students find the worksheet easy to use and practical, making them happy to do inquiry and relate examples of momentum and impulse events to traditional games. In line with (Wartono et al., 2018), students who carry out the inquiry process in learning physics and watch videos on the application of relevant topics, will make them do a lot of exercise during learning and also positively affect higher order thinking skills.

However, the results in offline class are better than those in online class. This is because students in offline class can discuss freely with the teacher, can communicate ideas directly, and are guided by the teacher. Although actually both in terms of average grades and the inquiry process from online class is also good (in Problem Approach and Making Hypotheses process). In fact, the role of the teacher in the classroom cannot be replaced in terms of guiding students because it has to do with providing direct emotional motivation, so that the student learning process becomes more enjoyable and optimal (in the other inquiry process, offline class got better average score than online class). Percentage of inquiry process achievement in online and offline class both are $>85 \%$, so this worksheet effectively can be used during covid-19 pandemic. The further researchers can test the worksheet on the law of conservation of momentum, the coefficient of restitution, and the types of collisions in online and offline classes and see the difference in the results. They can also use this momentum and impulse worksheet package to test its effectiveness in improving students' conceptual understanding.

\section{References}

Adler, I., Schwartz, L., Madjar, N., \& Zion, M. (2018). Reading between the lines: The effect of contextual factors on student motivation throughout an open inquiry process. Science Education, 102(4), 820-855. https://doi.org/10.1002/sce.21445

Arsal, Z. (2017). The impact of inquiry-based learning on the critical thinking dispositions of preservice science teachers. International Journal of Science Education, 39(10), 1326-1338. https://doi.org/10.1080/09500693.2017.1329564

Atmojo, S. E., Muhtarom, T., \& Lukitoaji, B. D. (2020). The level of self-regulated learning and selfawareness in science learning in the covid-19 pandemic era. Jurnal Pendidikan IPA Indonesia, 9(4), 512-520. https://doi.org/10.15294/jpii.v9i4.25544

Chernikova, O., Heitzmann, N., Stadler, M., Holzberger, D., Seidel, T., \& Fischer, F. (2020). Simulationbased learning in higher education: A meta-analysis. Review of Educational Research, 90(4), 499-541. https://doi.org/10.3102/0034654320933544 
Momentum: Physics Education Journal, 5 (2), 2021, 173

Habibah Khusna Baihaqi, Jumadi Jumadi, Annisaa' Mardiani, Racy Religia

Chu, S. K. W., Reynolds, R. B., Tavares, N. J., Notari, M., \& Lee, C. W. Y. (2017). 21st Century learning skill. In 21st Century skills development through inquiry-based learning: From theory to practice (Issue August 2018, p. 210). Springer.

Clark, D. B., Tanner-Smith, E. E., \& Killingsworth, S. S. (2016). Digital games, design, and learning: A systematic review and meta-analysis. Review of Educational Research, 86(1), 79-122. https://doi.org/10.3102/0034654315582065

Fernandes, G. W. R., Rodrigues, A. M., \& Ferreira, C. A. R. (2019). Using ICT in inquiry-based science education. Springer International Publishing. https://doi.org/10.1007/978-3-030-17895-6

Juanda, A., Shidiq, A. S., \& Nasrudin, D. (2021). Teacher learning management: Investigating biology teachers' tpack to conduct learning during the covid-19 outbreak. Jurnal Pendidikan IPA Indonesia, 10(1), 48-59. https://doi.org/10.15294/jpii.v10i1.26499

Katz, S., \& Dack, L. A. (2014). Towards a culture of inquiry for data use in schools: Breaking down professional learning barriers through intentional interruption. Studies in Educational Evaluation, 42, 35-40. https://doi.org/10.1016/j.stueduc.2013.10.006

Kovačević, T., \& Opić, S. (2014). Contribution of traditional games to the quality of students' relations and frequency of students' association in primary education. Croatian Journal of Education, 16(Sp.Ed.No. 1), 95-112. https://doi.org/10.15516/cje.v16i0.958

Kunt, K., \& Tortop, H. S. (2017). Examination of science and technology teachers' attitude and opinions related giftedness and gifted education in Turkey. Journal for the Education of Gifted Young Scientists, 5(1), 37-54. https://doi.org/10.17478/JEGYS.2017.53

Leasa, M., Batlolona, J. R., \& Talakua, M. (2021). Elementary students' creative thinking skills in science in the Maluku islands, Indonesia. Creativity Studies, 14(1), 74-89. https://doi.org/10.3846/cs.2021.11244

Leasa, M., Talakua, M., \& Batlolona, J. R. (2016). The development of a thematic module based on Numbered Heads Together (NHT) cooperative learning model for elementary students in Ambon, Moluccas-Indonesia. New Educational Review, 46(4), 174-185. https://doi.org/10.15804/tner.2016.46.4.15

Mardiyanto, M. (2019). Lembar kerja siswa pembelajaran teks diskusi berdasarkan pendekatan genre bagi siswa sekolah menengah pertama. Arisen: Assessment and Research on Education, 1(1), 21-31. https://doi.org/10.33292/arisen.v1i1.24

Marsh, J. A., \& Farrell, C. C. (2015). How leaders can support teachers with data-driven decision making. Educational Management Administration \& Leadership, 43(2), 269-289. https://doi.org/10.1177/1741143214537229

Mayo, A., Sharma, M. D., \& Muller, D. A. (2009). Qualitative differences between learning environments using videos in small groups and whole class discussions: A preliminary study in physics. Research in Science Education, 39(4), 477-493. https://doi.org/10.1007/s11165-0089090-0

Oktasari, D., Jumadi, Warsono, Hariadi, M. H., \& Syari, E. L. (2019). 3D page-flipped worksheet on impulse-momentum to develop students' scientific communication skills. Jurnal Pendidikan IPA Indonesia, 8(2), 211-219. https://doi.org/10.15294/jpii.v8i2.15737

Purwaningsih, E., Sari, S. P., Sari, A. M., \& Suryadi, A. (2020). The effect of stem-pjbl and discovery learning on improving students' problem-solving skills of the impulse and momentum topic. Jurnal Pendidikan IPA Indonesia, 9(4), 465-476. https://doi.org/10.15294/jpii.v9i4.26432

Rahmawati, Rustaman, N. Y., Hamidah, I., \& Rusdiana, D. (2018). The development and validation of conceptual knowledge test to evaluate conceptual knowledge of physics prospective teachers on electricity and magnetism topic. Jurnal Pendidikan IPA Indonesia, 7(4), 483-490. https://doi.org/10.15294/jpii.v7i4.13490

Rani, S. A., Wiyatmo, Y., \& Kustanto, H. (2017). Concept attainment worksheet to enhance concept 
knowledge and science process skills in physics instruction. Jurnal Pendidikan IPA Indonesia, 6(2), 326-334. https://doi.org/10.15294/jpii.v6i2.10520

Roth, K. J., Garnier, H. E., Chen, C., Lemmens, M., Schwille, K., \& Wickler, N. I. Z. (2011). Videobased lesson analysis: Effective science PD for teacher and student learning. Journal of Research in Science Teaching, 48(2), 117-148. https://doi.org/10.1002/tea.20408

Saifullah, A. M., Sutopo, S., \& Wisodo, H. (2017). Senior high school students' difficulties in solving impulse and momentum problems. Jurnal Pendidikan IPA Indonesia, 6(1), 1-10. https://doi.org/10.15294/jpii.v6i1.9593

Schrijvers, M., Janssen, T., Fialho, O., \& Rijlaarsdam, G. (2019). Gaining insight into human nature: A review of literature classroom intervention studies. Review of Educational Research, 89(1), 345. https://doi.org/10.3102/0034654318812914

Scogin, S. C., \& Stuessy, C. L. (2015). Encouraging greater student inquiry engagement in science through motivational support by online scientist-mentors. Science Education, 99(2), 312-349. https://doi.org/10.1002/sce.21145

Serway, R. A., \& Jewett, J. W. (2018). Physics for scientists and engineers (3rd ed.). Cengage Learning.

Setiawan, A., Fajaruddin, S., Harun, M. H., Sumiyati, Y., Nartani, C. I., \& Fitriana, F. (2020). Character values in the thematic learning of elementary school. Sekolah Dasar: Kajian Teori Dan Praktik Pendidikan, 29(2), 158-169. https://doi.org/10.17977/um009v29i22020p158

Sinha, T., \& Kapur, M. (2021). When problem solving followed by instruction works: Evidence for productive failure. Review of Educational Research, XX(X), 003465432110191. https://doi.org/10.3102/00346543211019105

Strømme, T. A., \& Furberg, A. (2015). Exploring teacher intervention in the intersection of digital resources, peer collaboration, and instructional design. Science Education, 99(5), 837-862. https://doi.org/10.1002/sce.21181

Suchman, J. R. (1961). Inquiry training: building skills for autonomous discovery. Merrill-Palmer Quarterly of Behavior and Development, 7(3), 147-169.

Sutarto, Indrawati, Prihatin, J., \& Dwi, P. A. (2018). Geometrical optics process image-based worksheets for enhancing students' higher-order thinking skills and self-regulated learning. Jurnal Pendidikan IPA Indonesia, 7(4), 376-382. https://doi.org/10.15294/jpii.v7i4.14563

Trajkovik, V., Malinovski, T., Vasileva-Stojanovska, T., \& Vasileva, M. (2018). Traditional games in elementary school: Relationships of student's personality traits, motivation and experience with learning outcomes. PLOS ONE, 13(8), 1-15. https://doi.org/10.1371/journal.pone.0202172

Tsivitanidou, O. E. (2018). Professional development for inquiry-based science teaching and learning. Springer International Publishing AG.

Uiterwijk-Luijk, L., Krüger, M., Zijlstra, B., \& Volman, M. (2019). Teachers' role in stimulating students' inquiry habit of mind in primary schools. Teaching and Teacher Education, 86, 102894. https://doi.org/10.1016/j.tate.2019.102894

Wartono, W., Alfroni, Y. F., Batlolona, J. R., \& Mahapoonyanont, N. (2019). Inquiry-scaffolding learning model: Its effect on critical thinking skills and conceptual understanding. Jurnal Ilmiah Pendidikan Fisika Al-Biruni, 8(2), 249-259. https://doi.org/10.24042/jipfalbiruni.v8i2.4214

Wartono, W., Takaria, J., Batlolona, J. R., Grusche, S., Hudha, M. N., \& Jayanti, Y. M. (2018). Inquirydiscovery empowering high order thinking skills and scientific literacy on substance pressure topic. Jurnal Ilmiah Pendidikan Fisika Al-Biruni, 7(2), 139-151. https://doi.org/10.24042/jipfalbiruni.v7i2.2629 